Research Article

\title{
Variations in Profitability of Different Size of Commercial Broiler Poultry Farms in Central Region of Khyber Pakhtunkhwa
}

\author{
Mian Muhammad Arif* and Malik Muhammad Shafi
}

Institute of Development Studies, The University of Agriculture, Peshawar, Khyber Pakhtunkhwa, Pakistan.

\begin{abstract}
Profit maximization is one of the common objectives of business enterprises, which is grossly dependent on resources utilization. This study was carried out to determine the profitability of different size of commercial broiler poultry farms in central region of Khyber Pakhtunkhwa. A total of 105 sample broiler poultry farms were selected through random sampling technique and data were collected for 483 flocks by means of interview schedule. Descriptive statistics was used for general analysis, while budgetary technique was used for profitability analysis. Ordinary Leased Square (OLS) technique was employed to find the effect of different inputs on profit of broiler poultry farms. The ANOVA tool was used to know the variations in cost, revenue and profit of various size of commercial broiler poultry farms. Due to wide spread variations in cost and return pattern of various broiler poultry farms, subsequently, the farms have been divided into three major groups i.e. small, medium, and large size farms. It is evident from the results of partial budgeting that the average total cost per flock of small size broiler poultry farm was 1468290 rupees while the total average cost per flock of medium and large size broiler poultry farms were 2485249 and 4792247 rupees respectively. Feed was the major cost component of the broiler farms with more than $60 \%$ share in the total cost of production followed by chick cost with a percentage share of 19.72. Furthermore, figures showed the average total revenue, cost and profit of different size commercial broiler poultry farms. The empirical results of the log-transformed function show that cost of labour, day-old chicks, feed and flushing cost have a significant effect on the revenue of broiler poultry production while all other variables i.e. medicare, and miscellaneous cost turned out to be insignificant. The ANOVA results showed a statistically significant difference between the costs, revenue and profit of various sizes of broiler poultry farms at $5 \%$ level of significance. It is recommended that farmers should be provided loan facilities with a low-interest rate. The profitability of broiler poultry farms can be increased by reducing high mortality rate through proper vaccination, medication, and better management techniques.

Received | May 07, 2021; Accepted | June 06, 2021; Published | June 30, 2021

*Correspondence | Mian Muhammad Arif, Institute of Development Studies, The University of Agriculture, Peshawar, Khyber Pakhtunkhwa, Pakistan; Email: maref123@yahoo.com

Citation | Arif, M.M. and M.M. Shafi. 2021. Variations in Profitability of different size of commercial broiler poultry farms in central region of Khyber Pakhtunkhwa. Sarhad Journal of Agriculture, 37(3): 858-867.

DOI | https://dx.doi.org/10.17582/journal.sja/2021/37.3.858.867

Keywords | Profitability analysis, OLS technique, ANOVA, Commercial broiler, Poultry farms
\end{abstract}

\section{Introduction}

$\mathrm{P}$ akistan is a developing country with a rapid population growth rate. It has population of almost 210 million which means a huge demand for food protein. Like other countries of the world, poultry farming in Pakistan also is the most important component of agriculture. At present, poultry is one of the largest industries in Pakistan's economy with an investment of more than 1082 billion rupees. It is an agro-based industry with a contribution in agriculture and livestock as $7.5 \%$, and $12.7 \%$ respectively and 
in GDP $1.4 \%$. This industry generates employment opportunities for more than 1.5 million skilled, semiskilled and unskilled workers that help in alleviating poverty in rural areas (GOP, 2017-18). The share of poultry meat in total meat production in the country has increased from $31.17 \%$ in $2017-18$ to $33.56 \%$ in 2018-19 (GOP, 2018-19).

An inflationary jump has been observed in the prices of different types of meat during the last few years. Poultry has played the role of a balancing force to keep a check on the prices of beef and mutton. Poultry meat provides relief to consumers against a sharp increase in the prices of red meat. The supply of red meat is decreasing and therefore, poultry is the cheapest alternate available animal protein. It is also a check upon the increasing animal protein prices in the country. In Pakistan, $17.22 \%$ (31.0 million) of the population is undernourished. Among these, the majority are children under five years of age and such children remain weak throughout their lives. (FAO, 2012; UNSCN, 2004). According to another report, $33.04 \%$ of children under the age of five are underweight in Pakistan which clearly shows that the nutritional status in the country is poor (Nava and Ammara, 2012). They are suffering from different types of deficiencies including protein deficiency. The average consumption of animal protein is $17 \mathrm{gm} /$ person/day against the WHO standard of $27 \mathrm{gm} /$ person/day (GoP, 2017-18). This shows a considerable gap between the actual consumption level and the standard consumption level.

Poultry plays an important role in meeting the demand for animal protein. It is the cheapest and commonest source of high-quality animal protein and food (Udoh and Etim, 2007; Murtala et al., 2004; Ojo, 2002; Alam, 2000). Protein helps in digestion, metabolism, and storage of fats, creation of new cells and maintenance or replacement of the existing cells of the human body. With the increase in population, the need for good protein has also increased to meet the nutritional needs of human beings. Poultry production especially broiler production can help a lot in improving protein supply. Furthermore, broiler poultry provides short-term investment opportunities and helps in increasing meat availability which results in an improved living standard of the people (Oneyenweaku and Awuja, 1995). It becomes important to encourage farmers for broiler production because it carries less financial and technical constraints and requires fewer resources.

Profitability of poultry farms is extensively studied at various locations in the world and found that poultry business is profitable business (Afzal and Khan, 2017; Ali et al.,2014; Imtiaz, 2012; Banoet al., 2011; Sheikh and Zala, 2011; Singh et al., 2010; Mohsinet al., 2008; Oladeebo and Ambe-lamidi, 2007; Islam, 1998; Mian, 1994). In considering the various size of broiler poultry farms, it was found that large and small poultry farms possess large cost benefit ratio (Imtiaz, 2012; Islam, 1998) while Singh et al. (2010) found a direct relationship between BCR and farm size. Sheikh and Zala (2011) studied that the net margin over the rupee invested on broilers increases with the increase in size of broiler poultry farm. Oladeebo and Ambe-lamidi (2007) determined the profitability of poultry production and found it profitable among youth poultry farmers. Aflobai et al. (2013) estimated the profitability of poultry egg farming. The profitability rates reveal that any 1 (naira) investment has a potential return of 0.43 (Naira) net farm income.

Imtiaz (2012) reported that farmer's profitability in broiler poultry production was positively affected by farmer's education and experience and negatively by mortality of birds while Khan and Afzal (2018) found age of the farmer and size of the farm as two more factors which positively affect the farmer's profitability, Oluwatayo et al. (2016) analysed the profitability and efficiency of smallholder broiler production and also to determine factors that affects productivity in Mopani district of Limpopo province, South Africa. A positive correlation was found between the stock size and output of broiler produced. The study revealed that the output of the broiler increased with an increase in the spending on vaccines. A negative relationship was found between the farmer's age and his technical efficiency.

Very few studies have been carried out to analyse the structure and of the industry in Pakistan. Status of research on the subject in Khyber Pakhtunkhwa is even low. In Khyber Pakhtunkhwa studies on the subject matter mostly focused on very limited geographical area and are based on small samples. This study is designed to cover the methodological deficiencies noted in other studies. The hypothesis for this study is that there are no differences in the per flock profit of different sizes of broiler poultry farms and focus is on 
analysing profitability with reference to different farm size of commercial broiler poultry farms with wide coverage to Central Khyber Pakhtunkhwa region also known as Peshawar Valley which consist of District Peshawar, Nowshera, Charsadda, Swabi and Mardan. It will help to get a better picture of the situation of industry in the targeted area.

\section{Materials and Methods}

On the basis of climate and geography condition, the Khyber Pakhtunkhwa province is divided into three regions i.e. the Central, Southern and Northern Regions. The central region is known as Peshawar valley consisting of plain area surrounded by mountains from all sides. It comprises five districts i.e. provincial capital Peshawar, Nowshera, Mardan, Charsadda and Swabi. However, climate of the region is tropical and humid.

The Peshawar Valley is selected for conducting the present research on the basis of easy access, availability of data and socio-economic conditions. Therefore, all the poultry farmers of Peshawar Valley serve as universe of the study.

\section{Sampling frame, sampling technique and sample size}

To select samples from the study area, random sampling technique was used which overcome selection bias. To determine appropriate sample size the following statistical technique was used (Parel et al., 1973):

$$
n=K 2 \quad \delta 2 \quad N \text { Ne2 }+K 2 \delta 2
$$

Where; $\mathrm{n}$ is sample size, $\mathrm{K}$ is maximum accepted error. It is one third of the sample variance and its maximum value is $3, \delta^{2}$ is variance, $(\mathrm{e} / \mathrm{K}), \mathrm{e}$ is error, and, $\mathrm{N}$ is the size of population.

\section{Where; $\mathrm{K}=1 ; \delta^{2}=0.5 ; \mathrm{C}=5 \% ; \mathrm{N}=1284$}

Each district of the valley was considered as a separate independent population and an appropriate sample from each district was selected, based on the above statistical formula, in order to ensure that the selected sample truly represent the population. Selection of individual farmers/farms for interview were done randomly.

\section{Data sources and data collection}

The research was based on primary data which were collected for a period of one year through a pre tested interview schedule particularly designed for this study. Secondary data were used for reference and comparison where required. Secondary data were obtained from different research journals and official sites of the government of Pakistan and Khyber Pakhtunkhwa.

\section{Analysis of data}

For analysis of data, descriptive statistics, budgetary techniques and regression model were used.

\section{Descriptive statistics}

Descriptive statistics like mean, maximum, minimum, dispersion, etc were calculated in order to get some insight into the data. It helped in understanding the structure of investment and farm size etc. of the sampled farms.

\section{Budgetary technique}

The budgetary technique involves the cost and returns analysis. It was used to determine the profitability of broiler poultry farming.

$$
\operatorname{Profit}(\Pi)=T R-T C \quad \ldots \text { (2) }
$$

Total Revenue $(T R)=$ Total Farm output $($ TFO) $x$ Unit Price (P)

Total Cost $(T C)=$ Total Fixed Cost $(T F C)+$ Total Variable Cost (TVC) Gross Margin $(G M)=G R-T V C$ Net Farm Income $(N F I)=G R-T C$

\section{Regression analysis}

Ordinary Least Square (OLS) was used to determine the effect of the different inputs affecting the output of broiler poultry farming. Coefficients of inputs used under the Cobb-Douglas specification model were estimated and these were used to examine the inputuse efficiency and to estimate the return to scale value. To calculate the efficiency of the different inputs of production and nature of returns to scale in broiler poultry farming, the production function of the CobbDouglas type was used (Afzal and Khan, 2017). The function may be stated as under:

$$
Y=A X_{1}^{\beta 1} \cdot X_{2}^{\beta 2} \cdot X_{3}^{\beta 3} \ldots \ldots X_{n}^{\beta n} e^{\varepsilon} \quad \ldots \text { (4) }
$$

Where; $Y=$ Net Profit; $A=$ Constant (used for constant technology); $\mathrm{X} i=$ Inputs $(\mathrm{X} 1, \mathrm{X} i 2 \ldots)$ used in the production; $\mathrm{B} i=$ input productivity; $\mathrm{e}^{\varepsilon}=$ random error term. 
It is from the co-efficient of the input resources that the input-use efficiency was determined and subsequent returns to scale of the enterprise were determined. $\beta$ i's can be derived from the sample data with the help of Cobb-Doulas production function as: (Vincent et al., 2010).

$$
\ln Y=\beta_{0}+\beta_{1} \ln X_{1}+\beta_{2} \ln X_{2}+\ldots .+\beta_{n} \ln X_{n}+e^{\varepsilon} \ldots \ldots
$$

Where;

$\ln =$ Natural logarithm; $Y=$ Revenue of poultry farm; $\mathrm{X}_{1}=$ Cost of day-old chicks purchased; $\mathrm{X}_{2}=$ Cost of feed; $\mathrm{X}_{3}=$ Brooding cost $; \mathrm{X}_{4}=$ Flushing Cost $\mathrm{X}_{5}=$ Cost of medicine; $\mathrm{X}_{6}=$ Cost of labour; $\mathrm{X}_{7}=$ Miscellaneous cost; $\mathrm{e}^{\varepsilon}=$ Random error term.

Co-efficient $\beta_{1}$ is the percent change in output resulting from a one percent change in the input $X_{1}$. Similarly, the co-efficient on each input is the percent change in output resulting from a one percent change in the input. In a Cobb-Douglas production function, the sum of these co-efficient $\beta_{1}+\beta_{2}+\beta_{3}+\ldots \ldots+\beta_{n}$, is the degree of homogeneity, which measures whether the production function is constant, increasing or decreasing returns to scale. Three possibilities exist:

$$
\begin{aligned}
& \text { If }\left(\beta_{1}+\beta_{2}+\beta_{3}+\ldots \ldots+\beta_{n}\right)=1 \text { there exist constant } \\
& \text { return to scale } \\
& \text { If }\left(\beta_{1}+\beta_{2}+\beta_{3}+\ldots \ldots+\beta_{n}\right)<1 \text { there exist decreasing } \\
& \text { return to scale } \\
& \text { If }\left(\beta_{1}+\beta_{2}+\beta_{3}+\ldots \ldots+\beta_{n}\right)>1 \text { there exist increasing } \\
& \text { return to scale }
\end{aligned}
$$

\section{Results and Discussion}

The broiler poultry farms were categorized into three different classes/categories on the basis of the size of flock or capacity for birds. The farms were considered small if it has a capacity of up to 2000 birds. The broiler poultry farms were considered of medium size if their capacity ranges from 2001 to 4000 birds. Broiler Poultry farms with a capacity of more than 4000 birds were considered large broiler poultry farms. All this indicates that the surveyed area is predominantly occupied by medium size farms followed by small broiler poultry farms. It may be due to a lack of financial resources of the owners which do not allow the farmers to grow in size. It may also be due to the lack of experience of the farmers where they were not willing to bid risk at large-scale farming. Studies conducted by (Khan and Afzal,
2018; Afzal and Khan, 2017) also found similar trends in Dir lower district of Khyber Pakhtunkhwa. Similar studies conducted by various researchers have also divided the poultry farms into three categories (Dwivedi et al., 2016; Farooq et al., 2013).

Table 1: Distribution of sample respondents.

$\begin{array}{lll}\text { Location } & \text { Sample Respondents } & \text { Percent } \\ \text { Peshawar } & 31 & 29.52 \\ \text { Mardan } & 26 & 24.76 \\ \text { Swabi } & 21 & 20.00 \\ \text { Charsadda } & 13 & 12.38 \\ \text { Nowshera } & 14 & 13.33 \\ \text { Total } & 105 & 100.00\end{array}$

Source: Field Survey, 2018.

Table 2: Categorization of poultry farms.

$\begin{array}{llll}\text { Stratum } & \text { Farm size interval } & \begin{array}{l}\text { Number of } \\ \text { respondents }\end{array} & \begin{array}{l}\text { Percent- } \\ \text { age }\end{array} \\ \text { Small farm } & \text { Up to } 2000 & 35 & 33 \\ \text { Medium farm } & 2001-4000 & 52 & 50 \\ \text { Large farm } & 4001 \text { and Above } & 18 & 17 \\ \text { Total } & & 105 & 100\end{array}$

Source: Field Survey, 2018.

Table 3: Distribution by number of flocks.

\begin{tabular}{|lll} 
Number of flocks & Number of poultry farms Percent \\
\hline 1 & 02 & 02 \\
2 & 07 & 07 \\
3 & 18 & 17 \\
4 & 10 & 10 \\
5 & 34 & 32 \\
6 & 34 & 32 \\
\hline Total & 105 & 100 \\
\hline
\end{tabular}

Source: Field Survey, 2018.

The data show that majority of the sampled farmers had produced five to six flocks during the surveyed period. As a whole $65 \%$ of respondents reported production of five to six flocks. Similar results were also produced by researchers in Pakistan (Khan and Afzal, 2018; Afzal and Khan, 2017). It was also observed by researchers that a maximum up to six flocks were operated by farmers (Khan and Afzal, 2018; Bano et al., 2011).

\section{Mortality of birds}

Broiler farming is a risky business and the major risk 
faced by the farmers is the mortality of birds. Because of mortality of birds, farmers not only forego their revenue but also have to forego the cost incurred on raising the birds like purchasing cost, feed consumed, and medicare etc. Broiler chicks are living creatures and are highly susceptible to different diseases which can prove not only costly but deadly for farmers and the birds. The mortality of broiler chicks during production categorized on the basis of the size and capacity of farms is presented in the following Table 4. The lowest average mortality rate is reported in the largest capacity farms and the highest is reported in the smallest farm size. These findings are in line with findings of Farooq et al. (2013). It may be because the large farms are more economical than the small farms. To sum up, the size wise distribution shows that in the small farms average mortality rate is high as compared to large farms.

Table 4: Mortality of birds by farms' capacity.

\begin{tabular}{|c|c|c|c|}
\hline Size & Mortality (Percent) & Minimum & Maximum \\
\hline 2000 and below & 12.54 & 5.40 & 28.20 \\
\hline $2001-4000$ & 11.05 & 4.00 & 22.40 \\
\hline Above 4000 & 09.61 & 6.70 & 19.50 \\
\hline Average & 11.06 & 5.37 & 23.37 \\
\hline
\end{tabular}

Source: Field Survey, 2018.

\section{Cost per flock of different inputs}

In the calculation of the profitability of the broiler poultry farming, the cost is the major factor that can significantly influence the profitability. The cost of various sizes of broiler poultry farms was separately calculated. Table 5 shows the cost per flock of various inputs involved in various sizes of broiler poultry farms in the study area. The average cost per flock of small size broiler poultry farm was 1468290 rupees while the average cost per flock of medium and large size broiler poultry farms were 2485249 and 4792247 rupees, respectively.

\section{ANOVA for cost variation of different sizes of farm}

To know whether the cost was the same in different sizes of poultry farms or not, one-way ANOVA test was used. A statistically significant difference between the costs of various sizes of broiler poultry farms was recorded at a 5\% level of significance was determined by one-way ANOVA $(\mathrm{F}(2,97)=114.739, \mathrm{p}=.000)$ (Table 6).

Below Table 7 of multiple comparisons between the costs of various sizes of broiler poultry farms show the variations in the cost of various sizes of poultry farms. Results of the Tukey post-hoc test on a one-way ANOVA revealed a significant difference between the costs of different sizes of broiler poultry farms which took the large size and the medium size $(p=0.000)$, large size and small size $(p=0.000)$ and medium-size and small size $(p=0.000)$.

\section{Revenue of poultry farms}

The main and significant source of revenue was the sale of birds while a small share was also contributed by Gunny bags and litter in revenue of broiler poultry farm. The average total gross revenue per flock of small, medium and large size broiler poultry farms are given in the Table 8 .

\section{ANOVA for revenue of various size of poultry farms}

To verify that revenue was the same in different sizes of broiler poultry farms, one-way ANOVA test was used. The results show that there was a statistically significant difference between the revenue of various sizes of broiler poultry farms at a 5\% significance level as determined by one-way ANOVA $(\mathrm{F}(2,99)=$ $101.73, \mathrm{p}=.000)($ Table 9$)$.

Table 5: Average cost per flock of different variables of the varied size of broiler poultry farms (in Rs.).

$\begin{array}{lllllll}\text { Categories of cost } & \text { Small farms } & \text { Percent } & \text { Medium farms } & \text { Percent } & \text { Large farms } & \text { Percent } \\ \text { Chick cost (doc) } & 291746 & 19.87 & 497134 & 20.00 & 882811 & 18.42 \\ \text { Feed cost } & 906571 & 61.74 & 1562457 & 62.86 & 3094005 & 64.56 \\ \text { Brooding cost } & 35130 & 2.39 & 60001 & 2.41 & 77676 & 1.62 \\ \text { Flushing cost } & 13430 & 0.91 & 20696 & 0.83 & 38544 & 0.80 \\ \text { Medicare cost } & 85883 & 5.85 & 133772 & 5.38 & 303947 & 6.34 \\ \text { Labour cost } & 88697 & 6.04 & 133969 & 5.39 & 264235 & 5.51 \\ \text { Rent } & 35484 & 2.42 & 60209 & 2.42 & 102882 & 2.15 \\ \text { Miscellaneous cost } & 11349 & 0.77 & 17011 & 0.68 & 28147 & 0.59 \\ \text { Total } & 1468290 & 100 & 2485249 & 100 & 4792247 & 100\end{array}$

Source: Field Survey, 2018. 
Table 6: Differences in cost of various sizes of broiler poultry farms.

$\begin{array}{llllll}\text { Difference } & \text { Sum of square } & \text { D.F } & \text { Mean square } & \text { F ratio } & \text { P Value } \\ \text { Between groups } & 124286528697693.47 & 2 & 62143264348846.73 & 114.739 & .000 \\ \text { Within groups } & 52535650501817.05 & 97 & 541604644348.62 & & \\ \text { Total } & 176822179199510.50 & 99 & & & \end{array}$

Source: Field Survey, 2018.

Table 7: Multiple comparison table of cost of different sizes of broiler poultry farms.

\begin{tabular}{|c|c|c|c|c|c|c|}
\hline \multirow{2}{*}{$\begin{array}{l}\text { i group of the } \\
\text { farm }\end{array}$} & \multirow{2}{*}{$\begin{array}{l}\text { j group of the } \\
\text { farm }\end{array}$} & \multirow[t]{2}{*}{ Mean Difference (i-j) } & \multirow[t]{2}{*}{ Standard error } & \multirow[t]{2}{*}{ Sig. } & \multicolumn{2}{|c|}{$5 \%$ level of significance } \\
\hline & & & & & Lower bound & Upper bound \\
\hline \multirow[t]{2}{*}{ Large } & Medium & $2306998.02^{*}$ & 206618.46 & .000 & 1815200.38 & 2798795.65 \\
\hline & Small & $3323956.24^{*}$ & 219707.44 & .000 & 2801003.95 & 3846908.53 \\
\hline \multirow[t]{2}{*}{ Medium } & Large & $-2306998.02^{*}$ & 206618.46 & .000 & -2798795.65 & -1815200.38 \\
\hline & Small & $1016958.22^{*}$ & 165058.64 & .000 & 624082.15 & 1409834.28 \\
\hline \multirow[t]{2}{*}{ Small } & Large & $-3323956.24^{*}$ & 219707.44 & .000 & -3846908.53 & -2801003.95 \\
\hline & Medium & $-1016958.22^{*}$ & 165058.64 & .000 & -1409834.28 & -624082.15 \\
\hline
\end{tabular}

*The mean difference is significant at the 0.05 level

Source: Field Survey, 2018.

Table 8: Revenue per flock (in Rs.).

$\begin{array}{lllll}\text { Particular } & \text { Revenue from chick } & \text { Revenue from gunny bags } & \text { Revenue from litter } & \text { Total gross revenue } \\ \text { Small } & 366123(98.64 \%) & 802(0.22 \%) & 4225(1.14 \%) & 371150 \\ \text { Medium } & 553875(98.82 \%) & 1232(0.22 \%) & 5391(0.96 \%) & 560498 \\ \text { Large } & 902268(98.78 \%) & 2141(0.23 \%) & 9001(0.99 \%) & 913410\end{array}$

Source: Field Survey, 2018.

Table 9: Differences in revenue of various size of broiler poultry farms.

$\begin{array}{llllll}\text { Difference } & \text { Sum of Square } & \text { D.F } & \text { Mean square } & \text { F ratio } & \text { Sig. } \\ \text { Between groups } & 124761159125139.95 & 2 & 62380579562569.98 & 101.73 & .000 \\ \text { Within groups } & 59479949294245.93 & 97 & 613195353548.92 & & \\ \text { Total } & 184241108419385.88 & 99 & & & \end{array}$

Source: Field Survey, 2018.

Table 10: Multiple comparison table of revenue of different size of broiler poultry farms.

\begin{tabular}{lllllll}
$\begin{array}{l}\text { i group of } \\
\text { the farm }\end{array}$ & $\begin{array}{l}\text { j group of the } \\
\text { farm }\end{array}$ & Mean difference $(\mathbf{i}-\mathbf{j})$ & Standard error & Sig. & \multicolumn{2}{c}{ 5\% level of significance } \\
Large & Medium & $2236314.70^{*}$ & 219850.45 & .000 & 1713022.00 & 2759607.40 \\
& Small & $3334169.02^{*}$ & 233777.65 & .000 & 2777726.50 & 3890611.54 \\
\multirow{2}{*}{ Medium } & Large & $-2236314.70^{*}$ & 219850.45 & .000 & -2759607.40 & -1713022.00 \\
& Small & $1097854.31^{*}$ & 175629.11 & .000 & 679818.19 & 1515890.43 \\
\multirow{2}{*}{ Small } & Large & $-3334169.02^{*}$ & 233777.65 & .000 & -3890611.54 & -2777726.50 \\
& Medium & $-1097854.31^{*}$ & 175629.11 & .000 & -1515890.43 & -679818.19
\end{tabular}

Source: Field Survey, 2018.

A significant difference among the revenue of various results. Table of Multiple Comparisons given below sizes of broiler poultry farms is evident from the further indicates the variation in revenue among September 2021 | Volume 37 | Issue 3 | Page 863 
different sizes of broiler poultry farms individually. The results of Tukey post-hoc test indicates a significant variation in the revenue of various sizes of broiler poultry farms that took the large size broiler poultry farms and the medium size $(\mathrm{p}=0.000)$, as well as between the large size broiler poultry farms and small size $(p=0.000)$ and also between medium size poultry farms and small size poultry farms $(\mathrm{p}=$ 0.000) (Table 10).

\section{The profitability of various sizes of broiler poultry farms}

The profit of a broiler poultry farm can be calculated by subtracting the total cost of a broiler poultry farm from the total revenue of a broiler poultry farm. Table 11 shows total average revenue, total average cost and average total profit with standard deviation of different size of poultry farms.

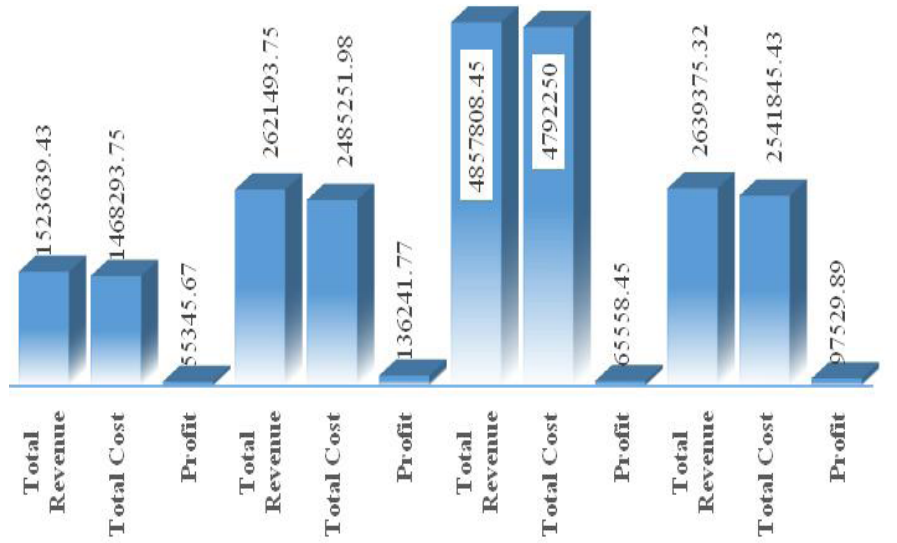

Figure 1: Revenue, cost and profit of different size of broiler poultry farm.
Table 11: Gross revenue, cost and profit of different sizes of broiler poultry farms (in Rs.).

\begin{tabular}{lllll}
$\begin{array}{l}\text { Poultry } \\
\text { farm }\end{array}$ & $\begin{array}{l}\text { Average to- } \\
\text { tal revenue }\end{array}$ & $\begin{array}{l}\text { Average } \\
\text { total cost }\end{array}$ & $\begin{array}{l}\text { Average } \\
\text { total profit }\end{array}$ & $\begin{array}{l}\text { Standard } \\
\text { deviation }\end{array}$ \\
\hline Small & 1523639 & 1468294 & 55345 & 85336 \\
Medium & 2621494 & 2485252 & 136242 & 140899 \\
Large & 4857808 & 4792250 & 65558 & 52506 \\
Combine & 2639375 & 2541845 & 97530 & 118958
\end{tabular}

Source: Field Survey, 2018.

ANOVA for variation in profit of different size of farms One-way ANOVA test was used to see whether profit was the same in different sizes of broiler poultry farms or not. A statistically significant difference between the profit of different sizes of broiler poultry farms was noted at a $5 \%$ significance level as determined by one-way ANOVA $(\mathrm{F}(2,99)=5.860, \mathrm{p}=.004)$.

From the results, a significant difference between the profits of different sizes of broiler poultry farms was observed. The results of the post-hoc Tukey test indicated a significant difference between the profits of different sizes of broiler poultry farms that took the medium and small size broiler poultry farms ( $p$ $=0.006$ ). However, at a $5 \%$ significance level, there were no significant differences among the profits of the large size, medium-size and small size broiler poultry farms $(\mathrm{p}=0.073,0.951)$, respectively (Table 13).

Table 12: Differences in the per flock profit of different sizes of farms.

\begin{tabular}{|llllll} 
Difference & Sum of square & D.F & Mean square & F ratio & Sig. \\
Between groups & 151031174688.542 & 2 & 75515587344.271 & 5.860 & .004 \\
Within groups & 1249910594641.687 & 97 & 12885676233.419 & & \\
Total & 1400941769330.230 & 99 & & &
\end{tabular}

Source: Field Survey, 2018.

Table 13: Multiple comparison table of the per flock profit of different size of broiler poultry farms

\begin{tabular}{lllllll}
$\begin{array}{l}\text { i group of } \\
\text { the farm }\end{array}$ & $\begin{array}{l}\text { j group of the } \\
\text { farm }\end{array}$ & Mean difference $(\mathbf{i}-\mathbf{j})$ & Standard error & Sig. & \multicolumn{3}{c}{ 5\% level of significance } \\
Large & Medium & -70683.31318 & 31869.96203 & 0.073 & -146540.8706 & Upper bound \\
& Small & 10212.78004 & 33888.87712 & 0.951 & -70450.2417 & 90875.8018 \\
Medium & Large & 70683.31318 & 31869.96203 & 0.073 & -5174.2442 & 146540.8706 \\
& Small & $80896.09321^{*}$ & 25459.54756 & 0.006 & 20296.7399 & 141495.4466 \\
\multirow{2}{*}{ Small } & Large & -10212.78004 & 33888.87712 & 0.951 & -90875.8018 & 70450.2417 \\
& Medium & $-80896.09321^{*}$ & 25459.54756 & 0.006 & -141495.4466 & -20296.7399
\end{tabular}

Source: Field Survey, 2018.

September 2021 | Volume 37 | Issue 3 | Page 864 
Estimation of model

The empirical results of the log-transformed model for estimation of the profit function of broiler poultry farm are stated in the below Table 14 .

The log-transformed function shows the effect of the cost of different inputs on the revenue of broiler poultry farms. The empirical results of the log-transformed function show that profit of poultry product of broiler was positively affected by the cost of labour, day-old chicks, flushing, feed, medicare and miscellaneous cost while it is negatively affected by the cost of brooding. A percent increase in the cost of labour, labour, day-old chicks, flushing, feed and medicare will increase the amount of broiler poultry produced by $0.133,0.376$, $0.051,0.278,0.108$ and 0.049 respectively, while a percent increase in brooding cost will decrease the revenue of broiler by $0.001 \%$, respectively. The results of the present study are also in conformity with the studies conducted by Khan and Afzal (2018), Khan and Afzal (2018) and Imtiaz (2012).

Table 14: Estimation of amount of production of broiler poultry farm.

$\begin{array}{lllll}\text { Independent variables } & \begin{array}{l}\text { Coeffi- } \\ \text { cient }\end{array} & \begin{array}{l}\text { Standard } \\ \text { error }\end{array} & \text { t-stats } & \begin{array}{l}\text { Signifi- } \\ \text { cance }\end{array} \\ \text { LN_LABOUR } & 0.133 & 0.043 & 3.098 & 0.003 \\ \text { LN_DOC } & 0.376 & 0.059 & 6.397 & 0.000 \\ \text { LN_FLUSHING } & 0.051 & 0.027 & 1.890 & 0.062 \\ \text { LN_FEED } & 0.278 & 0.046 & 6.003 & 0.000 \\ \text { LN_BROODING } & -0.001 & 0.022 & -0.040 & 0.969 \\ \text { LN_MEDICARE } & 0.108 & 0.040 & 2.730 & 0.008 \\ \text { LN_MISC. COST } & 0.049 & 0.041 & 1.185 & 0.239 \\ \text { Constant } & 2.891 & 0.361 & 8.019 & 0.000 \\ \text { R Square } & 0.977 & & & \\ \text { Adj. R Square } & 0.951 & & & \\ \text { F Statistic } & 278.424(\mathrm{P} \text { value }=0.000) & \\ \text { Return to Scale } & 0.994 & & & \\ \text { Durbin Watson } & 1.742 & & & \\ \text { N } & 105 & & & \end{array}$

Source: Field Survey, 2018.

As evident from t-ratios that at $5 \%$ probability level, cost of labour, day-old chicks, feed, flushing cost (@10\% probability level) and medicare have a significant effect on the revenue of broiler poultry production, as these variables turned out to be significant, while at the same probability level, all other variables turned out to be insignificant. The value of $\mathrm{R}$ Square indicates that $97 \%$ of the variation in the revenue of broiler poultry was due to the cost of labour, day-old chicks, flushing, feed, medicare, rent, brooding and miscellaneous cost. The $\mathrm{F}$ value shows the overall model is highly significant.

\section{Conclusions and Recommendations}

The study was designed to calculate the profitability of broiler poultry farms, to estimate the effects of different input factors on broiler poultry production in broiler poultry farms in Peshawar Valley of Khyber Pakhtunkhwa. Central region of Khyber Pakhtunkhwa is also known as Peshawar Valley and is comprised of five districts i.e. provincial capital Peshawar, Mardan, Swabi, Charsadda, and Nowshera. There were wide spread variations in cost and returns pattern of various broiler poultry farms, so, these farms have been divided into three major groups i.e. large farms, medium farms and small farms. The highest number or percentage of flocks were produced by District Peshawar followed by District Mardan, District Swabi, District Nowshera and District Charsadda respectively. The lowest average mortality rate was reported in the largest capacity farms and the highest was reported in the smallest farm size. It may be because the large farms are more economical than the small farms.

It is evident from the results of partial budgeting that the average total cost per flock of small size broiler poultry farm was 1468290 rupees while the total average cost per flock of medium and large size broiler poultry farms were 2485249 and 4792247 rupees respectively. Feed cost was the major cost component of the broiler farms accounts for more than $60 \%$ of the total cost of production followed by chick cost. The average total gross revenue per flock of small size broiler poultry farms was 371150 rupees while that of medium size was 560498 rupees and large size was 913410 rupees. There was a statistically significant difference between the revenue, cost and profit of various sizes of commercial broiler poultry farms. The annual figures show that in small size broiler poultry farms, the average total revenue, cost and profit were 1523639,1468294 and 55345 rupees respectively. In medium-size broiler poultry farms, the average total revenue, cost and profit were 2621494, 2485252 and 136242 rupees while the same for large firms were 4857808, 4792250 and 65558. While considering the combined figure of all the broiler poultry farms regardless of the size of a broiler poultry farm, the 
average total revenue, cost and profit figures were 2639375, 2541845 and 97530 rupees. The empirical results of the log-transformed function show that at $5 \%$ probability level, cost of labour, day-old chicks, feed, flushing and medicare have a significant effect on the revenue of broiler poultry production while all other variables i.e. brooding and miscellaneous cost turned out to be insignificant.

To optimize the profitability and increase the efficiency of broiler poultry farms in the study area, the following recommendations and suggestions are given in light of the present research.

- To efficiently run the broiler poultry business, broiler poultry farmers should be properly trained in the area of resource management to reduce production costs.

- Broiler Poultry farmers facing complicated and low credit facilities; therefore, it is recommended that farmers should be provided loan facilities with a low-interest rate.

- The profitability of broiler poultry farms can be increased by reducing the high mortality rate through proper vaccination, medication, and better management techniques.

- Research efforts should be directed at designing equipment and broiler housing. Feeding of broiler is another area in which research efforts will be rewarding.

\section{Novelty Statement}

The study focuses on analyzing profitability with reference to different poultry farm sizes of Peshawar Valley.

\section{Author's Contribution}

Mian Muhammad Arif: $\mathrm{PhD}$ scholar, who did research, data collection, analysis and wrote draft of the manuscript.

Malik Muhammad Shafi: Major supervisor, who supervised and provided technical guidelines.

\section{Conflict of interest}

The authors have declared no conflict of interest.

\section{References}

Aflobai, O.I., D.A. Adegbite, O.F. Ashaolu and S.O. Akinbode. 2013. Profitability and resources-use efficiency in poultry egg farming in
Ogun State, Nigeria. Afr. J. Bus. Mgt., 7(16): 1536-1540.

Afzal, M., and M. Khan. 2017. Economic analysis of broiler poultry farms: A case study of District Lower Dir. Sarhad J. Agric., 33(1): 183-188. https://doi.org/10.17582/journal. sja/2017.33.1.183.188

Alam, S.M. and M.A. Khan. 2000. Poultry Farming in Pakistan has developed as an important sub-sector of livestock. Nuclear Institute of Agric. Tando Jam, Pakistan. pp. 07-13.

Ali, S., S. Ali, R. Asif and M. Nawaz. 2014. Profitability and cost efficiency analysis of open shed broiler farmers in Punjab, Pakistan. Int. J. Econ. Commerce Mgt., 2(6): 01-10.

Bano, R., H. Shah, M. Sharif and W. Akhtar. 2011. Profitability index and capital turn over in open house broiler farming: a case study of district Rawalpindi. J. Agric. Res., 24: 1-4.

Dwivedi, S., M. Dolma and P.K. Sharma. 2016. Economics of small broiler units in Jammu District of Jammu and Kashmir State:J.Anim. Res., 6(1): 157-165. https://doi.org/10.5958/2277940X.2016.00026.7

FAO, 2012. Statistical Yearbook "World Food and Agriculture" Italy. http://www.fao.org/3/ i2490e/i2490e00.htm

Farooq, A., M. Ishaq, A.S. Nisar, A. Hassan and K. Nabi. 2013. Economies of scale in broiler farming in Khyber Pakhtunkhwa. Sarhad J. Agric., 29(1): 120-1206

GoP, 2009. Economics Survey of Pakistan. 200910. http://www.finance.gov.pk/survey/chapter_10/02_Agriculture.pdf

GoP, 2018. Economics Survey of Pakistan. 201718. http://www.finance.gov.pk/survey/chapters_18/02-Agriculture.pdf

GoP, 2019. Economics Survey of Pakistan. 201819. http://www.finance.gov.pk/survey/chapters_19/2-Agriculture.pdf

Imtiaz, 2012. Profitability analysis of poultry farming in district Peshawar. Unpublished thesis of M. Phil, Institute of Development Studies, The University of the Agriculture Peshawar-Pakistan.

Islam, F., 1998. An analytical evaluation of broiler farm unit in Malakand. M.Sc. thesis, Department of Poultry Husbandry, Sindh. Agric. Univ. Tandojam, Sindh- Pakistan.

Khan, M. and M. Afzal. 2018. Profitability analysis of different farm size of broiler poultry 
in district Dir (lower). Sarhad J. Agric., 34(2): 389-394. https://doi.org/10.17582/journal. sja/2018/34.2.389.394

Mian, A.M., 1994. Poultry production and animal husbandry. National Book Foundation, Islamabad.pp. 328.

Mohsin, A.Q., R. Riaz, S. Asad and A. Mushtaq. 2008. Profitability analysis of broiler production in Rawalpindi District. Pak. J. Agric. Sci., 45(4): 514-519.

Murtala N, U. Haman, S. Abdurahman, M.Y. Qwaram and O. Suleiman. 2004. Cost and return analysis of poultry egg marketing: A case study of Bauchi State. Annual Conference of the Nigerian Association of Agric. Econ. Ahmadu Bello University, Zaria, Nigeria. November 3-5.

Nava, A. and M. Ammara. 2012. Malnutrition in Pakistani children, its causes, consequences and recommendations. J. Pak. Med. Assoc., 62(3): 311. https://jpma.org.pk/PdfDownload/3324

Ojo, S.O., 2002. Analysis of productivity and risk factors in commercial poultry production in Osun State, Nigeria. 8(19-24): 25-29.

Oladeebo, J.O. and A.I. Ambe-Lamidi. 2007. Profitability, input elasticities and economic efficiency of poultry production among youth farmer in Osun State, Nigeria. Int. J. of Poult. Sci., 6(12): 994-998. https://doi.org/10.3923/ ijps.2007.994.998

Oluwatayo, I.B., Tanya A.M. and Mmapatla P.S. 2016. Profitability and efficiency analysis of smallholder broiler production in Mopani dis- trict of Limpopo Province, South Africa. J. Agribus. Rural Dev., 1(39): 145-154. file:///F:/ Articles/Mian\%20Arif/17_1_2016.pdf,https:// doi.org/10.17306/JARD.2016.17

Onyenweaku, C.E. and C.O. Awuja 1995. Allocative efficiency in pig production in Imo State, Nigeria. Model. Simul. Control. 28(2): 51-63.

Parel, F.P., G.C. Caldito and P.L. Ferrer. 1973. Sampling design and procedure. The Agriculture Development Council, New York.

Sheikh, A.S. and Y.C. Zala. 2011. Production performance and economics appraisal of broiler farms of Gujarat. 24: 317-323.

Singh, V.P., V.K, Sharma, M.S. Sidhu and H.S. Kingra. 2010. Poultry farming in Punjab: An economic evaluation and export competitiveness. Agric. Econ. Res. Rev., pp. 23.

Udoh, E.J. and N.A. Etim. 2007. Application of stochastic production frontier in the estimation of technical efficiency of cassava based farms in Akwa Ibom State, Nigeria. Agric. J., 2(6): 731735.

UN, Standing Committee on Nutrition 2004.

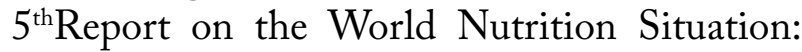
Nutrition for Improved Development Outcomes March-2004. https://www.unscn.org/ layout/modules/resources/files/rwns5.pdf

Vincent, N., B.K. Lagat, M.K. Korir, E.K. Ngeno and M.J. Kipsat. 2010. Resource use efficiency in poultry production in Bureti District, Kenya. $3^{\text {rd }}$ Afr. Assoc. Agric. Econ. Cape Town, S. Afr., pp. 19-23. 